\title{
Arctic Security Strategies and the North Atlantic States
}

\author{
Njord Wegge \\ Norwegian Defence University College, Military Academy, Norway
}

\begin{abstract}
New uncertainties in international relations have presented several states in the West with important choices regarding their national strategies for the Arctic. This article analyzes security challenges in the Arctic and North Atlantic region, as understood by some key North-Atlantic states, namely: the USA, Canada, Denmark, Norway, the UK, Germany and France. By analyzing how, or to what degree, the colder east-west security landscape since 2014 is reflected in these selected North Atlantic states' Arctic security strategies, this article seeks to improve our understanding of how the security situation in the northernmost part of the world is developing and being understood. Through applying a traditional understanding of security, the article identifies similarities but also significant differences among the Arctic and North-Atlantic states. Most notable when comparing the strategies is the rather unique global perspective laid out in the US security strategy for the region. The British, Norwegian, Danish and Canadian perspectives, on the other hand, stand out as more regional in nature. Germany displays a rather low profile in its approach to international security in the Arctic, considering its economic status in Europe. France reveals a strong concern for Arctic shipping and freedom of navigation, a perspective similar to the USA's, but with less global ambition.
\end{abstract}

Keywords: Arctic security, North Atlantic, strategies, defence, states

Responsible Editor: Nigel Bankes, Faculty of Law, University of Calgary, Canada

Received: May 2020; Accepted: October 2020; Published: December 2020

\section{Introduction}

New uncertainties in international relations have presented states in the West with some important choices regarding future security and defence planning in the Euro-Atlantic area and beyond. With the corona virus pandemic sweeping across the world in 2020, a new understanding of societal vulnerability has emerged. However,

\footnotetext{
^Correspondence to: Njord Wegge, email: nwegge@fhs.mil.no

(C) 2020 Njord Wegge. This is an Open Access article distributed under the terms of the Creative Commons Attribution-NonCommercial 4.0 International License (https://creativecommons.org/licenses/by-nc/4.0/), allowing third parties to share their work (copy, distribute, transmit) and to adapt it, under the condition that the authors are given credit, that the work is not used for commercial purposes, and that in the event of reuse or distribution, the terms of this license are made clear. 
tensions and uncertainties present before the pandemic are continuing to structure international relations today. Among the North Atlantic states, these uncertainties pertain to a more assertive, outward-looking Russia, as well as to the rise of China as a global superpower. In addition, western democracies questioning the robustness of a decades-old security architecture like NATO's is also new. ${ }^{1,2}$ These developments should be seen in parallel with the spread of populism, and through the lens of decades of downsizing defence spending in substantial parts of Europe, challenging credible national self-defence capabilities.

With an international situation characterized by renewed great power rivalry in the Arctic, it is important to follow key international stakeholders' security thinking with a careful eye. This article seeks to analyze the strategic thinking of some key North Atlantic states with respect to their Arctic strategies. In order to go deeper into the subjects under investigation, this article emphasises traditional ${ }^{3}$ aspects of security and defence. This is a focus that is widely applied within (main-stream) security studies, and the International Relations (IR) sub-discipline of "strategic studies" - a tradition that tends to be concerned with military capabilities and threats. ${ }^{4}$ Hence, this approach differs from investigations that apply an expanded understanding of security, which touch upon the societal and ecological dimensions ${ }^{5}$ of security. ${ }^{6}$ Within the tradition of strategic studies, the security of the state is usually at the core, alongside questions pertaining to great-power competition and the preservation of the status quo in the international system. ${ }^{7}$

Specifically, this article asks: 1) To what degree and to what extent are concerns over military threats reflected in the North Atlantic states' current Arctic security strategies?, and 2) Why and to what degree does the Arctic region have different strategic value to the North Atlantic states?

The selected North Atlantic states placed under scrutiny are the USA, Canada, Denmark/Greenland and Norway - all Atlantic states bordering the Arctic Ocean. In addition - to make the study more comprehensive - the three most prominent European powers, and Euro-Atlantic states, the United Kingdom, Germany and France, will also be investigated to create a more complete picture of the situation viewed from the North Atlantic region.

The paper begins with a brief review of key features of military power in the Arctic/ North Atlantic region, including an assessment of how these power capabilities play into the security politics of the region today. This review is followed by a mostly descriptive section assessing key Arctic security strategies of the North Atlantic states. Based on these two components, a discussion of the threats to Arctic security, including the region's strategic role for the different states under scrutiny follows.

The time focus of this article comprises 2014 and beyond. The year 2014 marks the year of Russia's annexation of Crimea, an important event in post-Cold War international relations. Concretely, the annexation, which is generally viewed as illegal in the West, was followed by strict economic and diplomatic sanctions by NATO 
and EU countries, along with NATO's enhanced focus on territorial defence. . $^{8,9,10}$ More specifically, the crisis led to the deployment of NATO troops to a number of states bordering Russia (the Baltic states and Poland) through the European Reassurance Initiative (2014), renamed the European Deterrence Initiative two years later. ${ }^{11}$ These developments led to a freeze in most political level contact between Moscow and EU/NATO countries, and a suspension in practical cooperation between Russia and NATO. ${ }^{12}$ While it can be debated just how deeply the Crimea crisis, in itself, divided Russia from the West in the Arctic, ${ }^{13,14}$ focusing on 2014 and beyond is a relevant time delineation for this article, given the above mentioned western responses to the event, and the topic under investigation.

With respect to the term "strategic"- having ancient roots and being heavily influenced by Clausewitzian thinking - this notion, in common usage within the discipline of strategic studies, essentially refers to the "level" where political and military considerations intersect. ${ }^{15}$ As such, NATO's official terminology offers a relevant definition, defining the "strategic level" as "the level at which a nation or group of nations determines national or multinational security objectives and deploys national, including military, resources to achieve them". ${ }^{16}$

As this article focuses on North Atlantic Artic security strategies, it does not provide an in-depth investigation of Russian strategies from a Russian perspective. While such an additional focus of investigation undoubtedly would have added depth and diversity to the analysis, the formal constraints of the article format have not allowed for this inclusion. Nevertheless, some of the most important Russian policy papers, with respect to Arctic security, will be briefly presented.

\section{Setting the stage: International relations and security in the Arctic}

For a long period, the Arctic has been a region of high geopolitical interest, while simultaneously representing a part of the world where peaceful interstate cooperation has existed. ${ }^{17}$ In this context the work of the Arctic Council, the role and boundaries of the Law of the Sea, issues pertaining to Arctic shipping, indigenous issues, Arctic resource management, and sustainable development, have been thoroughly examined in many studies. ${ }^{18}$ These studies have often applied a broad understanding of security, ${ }^{19}$ where issues stretching from societal and economic prosperity and stability, to climate change's effect on individuals, regional communities or indigenous people's livelihoods, have been scrutinized..$^{20,21}$ With the Russian flag planted on the sea floor of the North Pole in 2007, ${ }^{22}$ fueled by high energy prices and global warming, a wave of debate on Arctic geopolitics followed. ${ }^{23}$ While the media debate that followed the flag planting was largely centered on traditional aspects of security, the epistemological point of departure of many of the academic studies fits well within the tradition of critical geopolitics, by not having traditional aspects of state security and strategic interest at their core ${ }^{24,25}$ However, with the increased tensions following Russia's annexation of Crimea in 2014, the debate in the last few years has 
also led to greater interest in the genuine security and defence dimension ${ }^{26,27}$ of the Arctic, as found within the tradition of strategic studies. ${ }^{28,29}$ Many of these studies illustrate and discuss the tenser security dynamic in the High North, ${ }^{30}$ a situation that has also been characterized as the "new normal" in the East-West relationship. ${ }^{31}$

\section{Military power in the Arctic of today}

From the point of view of NATO and the North Atlantic states, the recent decadelong Russian re-armament ${ }^{32}$ program has not gone unnoticed. ${ }^{33}$ In the same way, the revival of the Russian bastion ${ }^{34}$ defence concept, centered around the key mission to protect Russia's strategic ballistic missile submarines (SSBN), has re-emerged as a key scenario for defence planning in the Arctic for the North Atlantic states. . $^{35,36}$

In unclassified western assessments of the Russian bastion defence planning concept, Russian armed forces are assumed to have an ambition to control the Barents Sea and its surrounding areas. ${ }^{37,38}$ In addition, Russia is assumed to seek to ensure sea and air denial in large parts of the Arctic Ocean as well as the Northernmost part of the Norwegian Sea, all the way south to the GIUK (Greenland, Iceland, UK) gap. ${ }^{39,40}$

As the Russian Northern Fleet gradually has been outfitted with highly capable and multi-layered air and coastal defence and denial capabilities, involving a "state of the art" S-400 air defence system, P-800 Oniks anti-ship cruise missiles, and Kalibr land attack cruise missiles, Russian systems for denial and control in large parts of the Arctic Ocean, the Barents sea and the Norwegian Sea, are credible. ${ }^{41}$

For these North Atlantic states, the central threat represented by the bastion defence, is linked to the assumption that Russia is likely to take far-reaching military measures in the Barents Sea and North Atlantic if threatened, measures taken in order to protect their SSBNs, which have the Barents Sea and Arctic Ocean as their primary operational theatre. ${ }^{42,43}$ As the SSBNs are generally assumed to represent the most credible deterrence through their second strike capability (given the difficulties to detect and neutralize such submarines for an opponent in a potential first strike), these military platforms are of the highest strategic value for Russia. ${ }^{44}$

In Russia, key documents from 2014 and beyond, with security implications for the Arctic are primarily; the 2014 "Military Doctrine", the 2015 "Russian National Security Strategy", the 2016 "Foreign Policy Concept of the Russian Federation" and the 2020 "Basic Principles of Russian and the Federation State Policy in the Arctic to 2035 " ${ }^{45,46}$ While the three former strategies have no direct link to the Arctic, they underscore a world that, seen from Russia, is characterized by global great power competition, pointing out NATO and the USA as the major external threats to Russian security. With respect to the latter Arctic-specific strategy, it is particularly important to note how this key document addresses concerns with respect to the steady increase in foreign military presence in the Arctic, particularly by NATO countries, as a challenge to its national security. ${ }^{47}$ This development is also reflected 
in the current Russian nuclear deterrence policy "Basic Principles of State Policy of the Russian Federation Nuclear Deterrence" (2020), which focuses on the threats posed by "individual states" and "military alliances" which would certainly include the USA and NATO. ${ }^{48}$

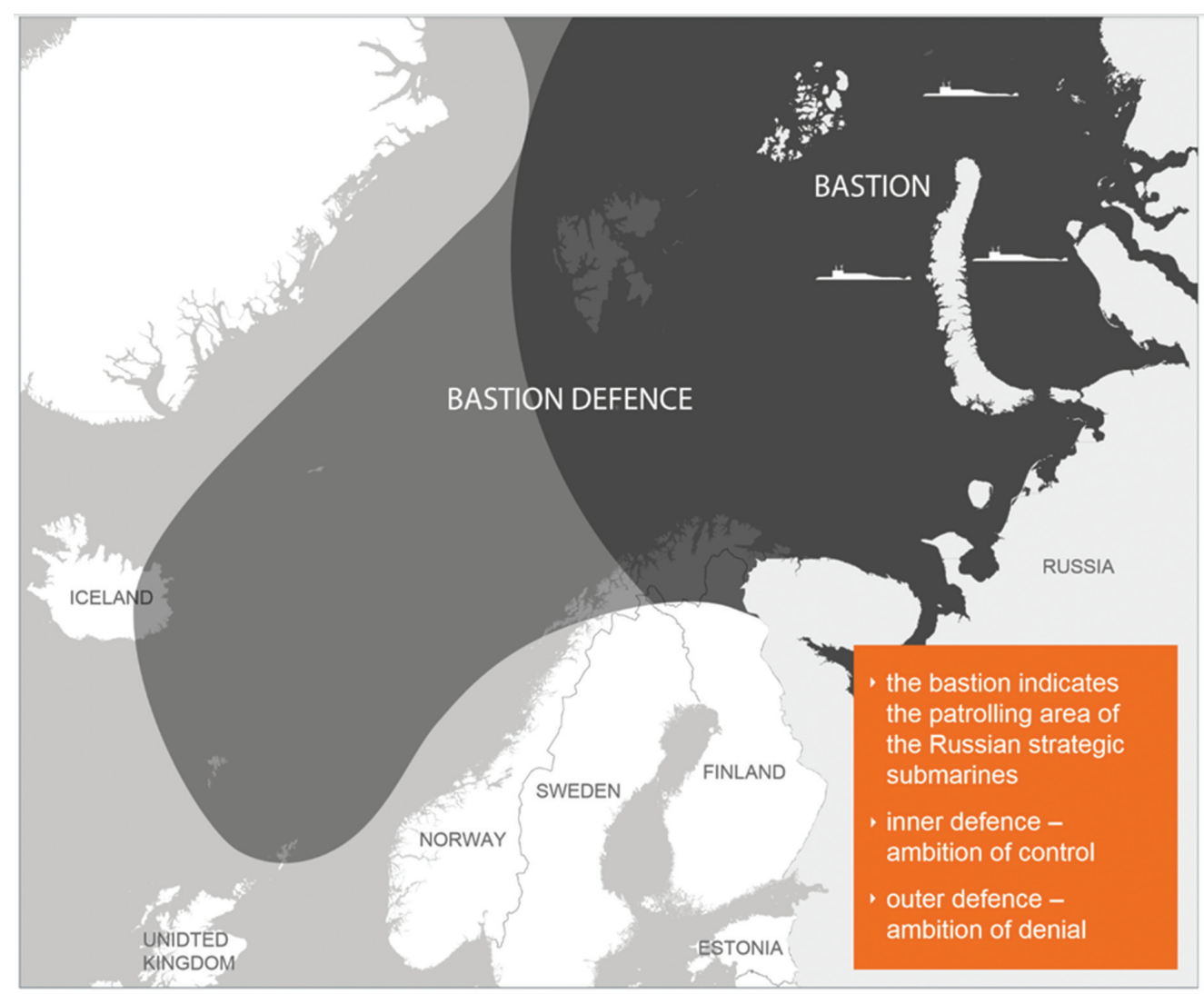

Fig. 1: "The Russian Bastion" where the darker color indicates the area where Russia is assumed to control the sea, air and land space in case of a major conflict, while the lighter color indicates the area where Russia is assumed to seek to deny hostile activity. (Expert Commission 2015: 21).

The revival of the bastion defence concept and the expansion of cold war military bases in the Arctic has raised worries from Washington DC to Oslo. According to the Danish intelligence service, Russia's military build-up in the Arctic "is particularly focused on the Nagurskoye fighter aircraft base in the Franz Josef's Land archipelago, located some $1,000 \mathrm{~km}$ from the North Pole". ${ }^{49}$ This is a base that is likely to be operational in 2020, "making it the world's northernmost combat aircraft base [...] becom[ing] a cornerstone of a forward line of defence in the Arctic Ocean" ${ }^{50}$ The report further underscores that while "Russia's military build-up in the Arctic $[\ldots]$ has a defensive focus, it increasingly contains elements that could also be 
utilized for offensive operations".${ }^{51}$ With respect to the above-mentioned air base at Franz Josef's land, this base will represent a key land component in both the control and denial dimension if the bastion defence is activated. "[T]he base will be able to accommodate even the largest transport, bomber and antisubmarine aircraft". ${ }^{52}$ Following this, "Russian combat aircraft deployed at the base could quickly reach the north-easternmost parts of Greenland and, using long- range missiles or air-to-air refueling, they would have the ability to attack the United States'Thule Air Base". ${ }^{53}$ This strategic role is also pointed out by the Canadian IR scholar Rob Huebert's statement that, "The location of Nagurskoye Base allows for much closer access to North America by Russian bombers. This, combined with the longer ranges of the new generation of hypersonic cruise missiles and the nuclear-powered submarine drones, increases the risk to North American targets". ${ }^{54,55}$ In a similar way, the many years of construction work and upgrading at the Northern Fleet's headquarters and surrounding bases in Severomorsk has been associated with the revival of the bastion defence concept. ${ }^{56}$ According to Fanes Intelligence Review, these bases have partly been upgraded to facilitate new submarines, ships and entire new weapon systems: "The upgrade has coincided with the Russian military's increased activities in the Arctic. These upgrades ensure that the Northern Fleet is able to provide the new service for Arctic expansion". ${ }^{57}$

Additionally, the Norwegian intelligence service points out in its public 2020 "Focus report", that the upgrade of the bastion defence and the more precise and advanced weapon systems being deployed on its border, give reason for concern. The same report highlights "broader complexity" and the "new scalability" of the Russian armed forces, as a key development. Such complex operations have been demonstrated by recent large-scale exercises: "Whereas the development and addition of new capabilities shows how Russian defences are being strengthened, Russia's military activity near Norwegian borders since the summer of 2019 has been one continuous demonstration of the defence concept's emphasis on integration and scalability". ${ }^{58}$ The same report also states how the bastion defence concept has been put into practice: "In August the Northern Fleet, together with the Baltic Sea Fleet, staged the largest naval exercise seen near Norwegian borders since the Cold War. Parts of the Bastion Defence were established all the way down to the North Sea." ${ }^{259,60}$

Seen from the West, the new Russian military capabilities and bases under construction give reason for concern, especially since they coincide with a significant increase in the level of training and military exercises taking place in the Arctic and North Atlantic region. ${ }^{61}$ In addition, there is growing unease about the potential new role and challenge posed by China as a gradually more active Arctic power, even though the scope of China's current military activities in the Arctic is much smaller. ${ }^{62}$ Nevertheless, China and Russia have recently extended their military talks at the commander level to discuss potential cooperation in the High North. ${ }^{63}$ 
The increase in Russian military activity in the Arctic is also reflected on the western side: a situation that has made observers warn of an arms race in the High North. ${ }^{64}$ Illustrative of an increasing western interest in its warfighting capacities in the Arctic is NATO's new focus on winter training in Norway. While these exercises began as far back as 2008 with Cold Response, the latest Trident Juncture exercise in the autumn of 2018 is illustrative of an increase in numbers and complexity, with the involvement of about 50,000 personnel and a US aircraft carrier strike group, representing NATO's largest exercise in Norway since the Cold War. ${ }^{65,66}$ Other novel developments since the Crimea crisis of 2014 is the rotating presence of US marines in northern and central Norway ${ }^{67}$ the re-establishing of the US $2^{\text {nd }}$ fleet in the Atlantic (2018), ${ }^{68}$ and the establishment (2019) of the Joint Force Command (Norfolk) tasked with keeping the sea lines of communication between America and Europe open. ${ }^{69}$

Last year's annual anti-submarine warfare exercises, Dynamic Mongoose, focusing on high intensity, symmetric warfighting and under ice operations in the Arctic Ocean is also an indication of the North Atlantic states' increased interest in security and defence dimensions in the Arctic. ${ }^{70}$ Finally, besides the large scale multinational military exercises, one can also observe a changing pattern in more regular Western naval operations. Most prominently, the US Navy has now started to conduct "freedom of navigation" operations in the Arctic, as witnessed in the Barents Sea in May $2020,{ }^{71}$ which also included a multinational (USA, UK, Denmark, Norway) exercise within the Russian EEZ ${ }^{72}$ in September $2020 .{ }^{73}$ This is a type of US naval activity not seen in these Arctic waters since the height of the Cold War. ${ }^{74,75}$

The trend for more naval activities in the North Atlantic and Arctic region also has its equivalent in increased military aviation in the High North. Illustrative of this are more frequent flights by strategic bombers including $\mathrm{B}-2 \mathrm{~s}^{76}$ and $\mathrm{B}-52 \mathrm{~s},{ }^{77}$ as witnessed in Iceland, above the Arctic Circle off the coast of Norway, and in the Barents Sea in the fall of 2019 and late summer of $2020 . .^{78,79}$

\section{Security strategies in the Arctic viewed from the North Atlantic states}

The Canadian Professor Rob Huebert has stated "The Russians are very determined to build up their military in the Arctic. They mean what they say and are willing to act", referring to how the location of the aforementioned Nagurskoye base represents new risks for North American targets. ${ }^{80}$ Huebert is not alone in his concerns. In a 2018 study, Professor RolfTamnes calls for a 'competitive strategy' for the High North: "The High North is central to a Europe 'free, whole and at peace' ... [therefore] NATO should formulate a competitive strategy, taking advantage of its own strengths and of Russia's weaknesses". ${ }^{81}$ Washington DC-based Arctic security researcher, Heather A. Conley, is also critical of the lack of US engagement in the Arctic: "As the United States has stood by, rivals such as Russia and China have seized that opportunity both economically and militarily, and their intentions are 
not wholly benign". ${ }^{82}$ Others, like Lieutenant Colonel and Professor Tormod Heier, warn of the increased risk of war with the spreading of a zero-sum security logic in the Arctic and northern Europe, observing how the Nordic countries have been preoccupied with "rapidly raising the costs of aggression, scaring Russia from assertive action", instead of "pursuing self-restraints as a means of building confidence" ${ }^{83} \mathrm{~A}$ similar argument has also been voiced by other Arctic experts, like Jeremy McKenzie, a Lieutenant Commander in the U.S. Coast Guard and researcher for the Center for Arctic Study and Policy, who states: "The United States and other Arctic states should continue to enhance their cooperative relationship with Russia in the Arctic while at the same time using the full range of policy to continue to condemn Russia's illegal actions in other parts of the world". ${ }^{44}$ However, other academic voices, like Professor Lassi Heininen, argue that the Arctic has experienced increased global conflict and tension to a lesser extent than other regions, essentially suggesting that little has changed with respect to the security situation in the Arctic. ${ }^{85}$

As the military features of great power rivalry are becoming more visible in the Arctic, as elsewhere, a recent report to Congress warns that this could challenge the traditional American leadership role in this region. ${ }^{86}$ The following outline takes a closer look at the North Atlantic states' security strategies in the Arctic; these should be carefully assessed when analyzing the official security thinking of these selected states.

\section{The USA}

The USA is an Arctic state and the world's only superpower. As the lead nation in NATO, carrying the backbone of the alliance's military capabilities - in addition to being the world's most important democracy - the USA plays a unique role in any security calculation by the North Atlantic states. The "Department of Defence (DoD) Arctic Strategy" was launched in June 2019. ${ }^{87}$ This strategy gives the most comprehensive expression of the US government's views on the security situation in the Arctic. In addition, one should note that the US Coast Guard's "Arctic Strategic Outlook" from $2019^{88}$ has a complementary function, specifically addressing the role of the coast guard in the north. Similarly, the US Air Force has also introduced its own Arctic Strategy, launched in July 2020. ${ }^{89}$

Anchored in the 2018 National Defence Strategy (NDS), ${ }^{90}$ the 2019 DoD Arctic Strategy identifies strategic competition from China and Russia - not only in the Arctic, but more generally - as the principal challenge to US security interests and future prosperity. ${ }^{91}$ "The Joint Force must be able to deter, and if necessary, defeat great power aggression. DoD must prioritize efforts to address the central problem the NDS identifies - i.e. the Joint Force's eroding competitive edge against China and Russia." 92

The resurgence of nation state competition is also highlighted in the Coast Guard's Arctic strategy: "Since the release of the Coast Guard Arctic Strategy in 2013, the 
resurgence of nation-state competition has coincided with dramatic changes in the physical environment of the Arctic, which has elevated the region's prominence as a strategically competitive space. America's two nearest-peer powers, Russia and China, have both declared the region a national priority". ${ }^{93}$ A somewhat similar perspective is also indicated by the Air Force's strategy stating: "Residing at the intersection between the U.S. homeland and two critical theaters, Indo-Pacific and Europe, the Arctic is an increasingly vital region for U.S. national security interests. The Arctic's capacity as a strategic buffer is eroding, making it an avenue of threat to the homeland, due to advancements by great power competitors." ${ }^{\prime 94}$

The DoD views the Arctic security environment as complex. While acknowledging that certain "positive, cooperative trends endure in the region", in particular, the US's strong defence relationships with the six other Arctic states, the strategy states that "the region is increasingly uncertain", and an area where "problematic strategic trends" are deepening and becoming more intense. ${ }^{95}$ The identified uncertainties are, on the one side, dependent on climatic factors, such as the consequences of decline in sea ice, while on the other hand, these uncertainties also pertain to political and military issues.

The DoD strategy recognizes that Arctic nations historically have "sought to isolate the region from wider geopolitical conflict"; however, the reported Russian threat "to use force against vessels that fail to abide by Russian regulations" (in the Northern Sea Route), represents a new type of uncertainty. ${ }^{96}$ The DoD strategy also points out how the security environment is changing as the strategic competitor, Russia, establishes or re-establishes military bases and facilities on its Arctic islands and coastal areas. ${ }^{97}$

Finally, the DoD strategy also notes significant concerns about China, potentially posing a risk through "attempts to alter Arctic governance through economic leverage". 98

Given a security climate characterized by great power rivalry and competition, the DoD points out the following objectives for the US security strategy in the Arctic: 1) "To defend the homeland"; 2) to "compete when necessary to maintain favorable regional balances of power", acknowledging "the Arctic as a potential avenue for expanding great power competition and aggression"; and 3) to "ensure common domains remain free and open". ${ }^{99}$

To reach these strategic objectives the DoD points to a strategic approach for the Arctic that emphasises cooperation with allies and partners in the region, while underscoring that the US must ensure credible deterrence "to deter strategic competitors from aggression in the Arctic". ${ }^{100}$ "The US Arctic deterrent will require agile, capable and expeditionary forces with the ability to flexibly project power into and operate within the region". ${ }^{101}$ In this respect, the Air Force strategy specifically states: "once the planned F-35 bed-down at Eielson AFB is complete, Alaska's unparalleled concentration of fifth generation fighters will present a highly-effective power projection capability". ${ }^{102}$ 
Both the DoD and the Air Force strategy also emphasize that the US will work with its Arctic allies and partners to ensure power projection, ${ }^{103}$ deter aggression, and prevent strategic competitors using the "Arctic as a corridor for expanded competition enabling their objectives in other regions". ${ }^{104}$ The partners and allies are indeed valued as essential to the US strategic interests: "The network of U.S. allies and partners with shared national interests in this rules-based order is the United States' greatest strategic advantage in the Arctic region, and thus the cornerstone of DoD's Arctic strategy". 105 "Maintaining freedoms of navigation and overflight are critical to ensuring that the Arctic remains a free and open domain [...] DoD will continue to fly, sail and operate wherever international law allows [...] When necessary and appropriate, the United States will challenge excessive maritime claims in the Arctic to preserve the rule based international order.”106

\section{Canada}

Canada is an Arctic state, a key NATO ally, but not a superpower with global security ambitions. Canada's Arctic security strategy is primarily pointed out in the "Safety, security, and defence" chapter in the Arctic and Northern Policy Framework. ${ }^{107}$ In addition, the Canadian armed forces general policy "Strong, Secure, Engaged" also offers insight into Arctic security thinking as viewed from Ottawa. ${ }^{108}$

In the Arctic and Northern Policy Framework, the Canadian Government focuses on the goal of keeping "The Canadian Arctic and North and its people [...] safe, secure, and well-defended". ${ }^{109}$ It further emphasizes the goal of enhancing Canada's military presence in the northern part of the homeland, including improving its awareness, surveillance, and control capabilities. ${ }^{110}$

Participation in the North American Aerospace Defence Command (NORAD), including the North Warning System (NWS), is a vital part of Canada's Arctic security engagement and represents a key pillar in US-Canadian Arctic security cooperation. ${ }^{111}$ In this respect the key, armed forces strategy document, "Strong, Secure, Engaged" states that, "While the current NWS is approaching the end of its life expectancy from a technological and functional perspective, unfortunately the range of potential threats to the continent, such as that posed by adversarial cruise missiles and ballistic missiles, have become more complex and increasingly difficult to detect". ${ }^{112}$ Canada's ongoing work with the United States "to ensure that NORAD is modernized to meet existing and future challenges" is a key point in order to meet this new unpredictability in a more complex arctic security environment. ${ }^{113}$

The Canadian Armed forces recognize that "a degree of major power competition has returned to the international system" and that "the Arctic region represents an important international crossroads where issues of climate change, international trade, and global security meet". ${ }^{114}$ The armed forces further underscore that "re-emergence of deterrence" has occurred, and that "changes in the international environment demand a new understanding of how and when to 
lawfully use or threaten to use military force". ${ }^{115}$ However, Canada's security focus is essentially regional and internally oriented, focusing on the need to protect the North American continent and the sovereignty of the Canadian homeland and its local residents.

\section{Denmark/Greenland}

Denmark is an Arctic state through its unique political and historic relationship with Greenland. With Greenland's geopolitical importance on the rise, Denmark's security thinking has implications way beyond the Arctic island itself. The current Danish security strategy for the Arctic is found in the Ministry of Foreign Affair's "Foreign and Security Policy Strategy 2019-2020". ${ }^{116}$ In addition, the pre-Crimea crisis "Kingdom of Denmark, Strategy for the Arctic 2011-2020", ${ }^{117}$ as well as the broad parliamentarian "Defence Agreement 2018-2023", 118 provide important insight into the direction of Danish security thinking in the Arctic.

When assessing the MFA strategy, one can read that "the international order that has shaped the world in recent decades can no longer be taken for granted". ${ }^{119}$ With respect to the Arctic, the government acknowledges "the significant and growing geopolitical interests in the region" and its desire to follow closely "the continued Russian military build-up [...] and expansion of forward bases on the Russian Arctic Islands". ${ }^{120}$ On the one hand, the strategy states that Copenhagen seeks to make the Arctic a "low-tension area", but on the other hand, it also stresses how NATO has intensified its focus on the Arctic. ${ }^{121}$

While the pre-Crimea crisis Arctic strategy focuses on the promise of increased cooperation with Russia, even within defence, the multi-party defence agreement of 2018 has abolished this goal and is now painting a gloomier picture, stating that NATO now "faces a challenging and more assertive Russia". ${ }^{122}$

\section{Norway}

Norway is an Arctic state located in the northwest corner of Europe. The current key documents illuminating Norwegian security thinking in the Arctic are "Norway's Arctic Strategy - between geopolitics and social development" (Government of Norway 2017) ${ }^{123}$, as well as the MFA White Paper: "Setting the course for Norwegian foreign and security policy". ${ }^{124}$ Viewed from Oslo, the Arctic has been a stable part of the world characterized by low tension for several years. However, the Arctic strategy points out new reasons for concern: "Over the last ten years, Russian military activity in the north has increased. This increase in activity is not considered to be targeted at Norway, but it is nevertheless an important factor in Norway's security and defence policy". ${ }^{125}$ The Norwegian MFA further states that: "Russia's annexation of Crimea in 2014 has changed the security situation. As a result, NATO has shifted its attention from out-of-area crisis management to collective defence and deterrence within the NATO area". ${ }^{126}$ 
With respect to the modernization of Russia's strategic forces in the north, and its relationship to the North-Atlantic and Arctic region, the MFA points out the following. "Norway wants to have good neighbourly relations with Russia, and the Government gives high priority to dialogue with the Russian authorities". ${ }^{127}$ Questions of military security have nevertheless risen on the agenda, and new concerns have become more prominent: "In the event of a security crisis, Russia could increase the readiness of these forces. This would reduce Norway's freedom of action and movement on its own territory and limit Allied access to the North Sea and the North Atlantic. A situation of this kind would make it more difficult for NATO to provide supplies and reinforcements for the defence of Norway and other Allies". ${ }^{128}$ With Russia's great power ambitions becoming clearer in the last decade, the Norwegian MFA points out in particular how "Russia's interventions in Georgia in 2008 and Ukraine in 2014 [have shown that] Russia is willing and able to use all the instruments of state power, including military force, to safeguard its interests. The use of military force in violation of international law creates uncertainty". ${ }^{129}$ The new Arctic security environment has also led to an increase in allied training and exercises in the Northern parts of Norway over the last few years, both by NATO as well as bilateral partners such as the USA and UK. ${ }^{130}$

\section{United Kingdom}

As an island nation in the North Atlantic, the Arctic region has always been of significant interest to the UK. "Beyond the Ice, UK policy towards the Arctic" is the current overall UK strategy for the Arctic. ${ }^{131}$ While this strategy touches on security issues, and for example states its concern for "the build-up of Arctic military capabilities by several Arctic states", the strategy does not present British views on the security dimension of the Arctic in any detail. ${ }^{132}$ The most comprehensive official document specifying the UK's strategic interests in the Arctic is the House of Commons, Defence Committee's report: "On Thin Ice: UK Defence in the Arctic" (2018). ${ }^{133}$ This report conducts a thorough and investigative approach to the security situation in the North Atlantic and Arctic region, followed up by recommendations for action.

While the Arctic, as seen from London, has been an area of low tension and multi-lateral cooperation in recent years, the House of Commons has now "identified the Arctic and the High North as an area of concern, largely due to the increasingly clear evidence of Russian military expansion". ${ }^{134}$ While the report also mentions uncertainties pertaining to the new Chinese interests in the Arctic, Russia remains the greatest reason for concern. ${ }^{135}$ The report further warns that "there is a risk that the perception of the Arctic as an area of exceptionalism where unique considerations of governance apply [...] could be exploited by nations which have shown an increasing disregard for the rule-based international order elsewhere". ${ }^{136}$ The report states that "the strategic importance of the High North and the North Atlantic to the 
security of the UK and Europe cannot be overstated", and recent developments in the Arctic are assessed to be of grave importance to the United Kingdom. ${ }^{137}$

The most fundamental concern for the UK's security interest in the Arctic and the High North is the fear of Russia using the Arctic military theatre to threaten or even block communication lines between America and Europe over the North Atlantic.

Threats from the "bastion defence concept" including sea control/sea denial, from the Arctic Ocean to the northern shores of Great Britain, - the GreenlandIceland-UK (GIUK) gap - have again become a challenge to maritime surveillance of the North Atlantic states: "The level of Russian naval activity has grown significantly $[\ldots]$ there has been a tenfold increase in Russian submarine activity in the North Atlantic. Russian submarine activity up to the GIUK Gap has been reported as being "currently equaling or surpassing Cold War levels"."138 "The newest class of multi-role nuclear powered submarines, the Yasen class, combines the capabilities of an attack submarine with powerful guided missile systems. Crucially, these new platforms use the latest quieting technology to make them as undetectable as possible." ${ }^{139}$

Hence the House of Common report states: "Although we are not facing challenges on the same scale today, the prospect of Russian power being projected from the High North into the North Atlantic has returned and a comprehensive strategy is needed to meet the threat". ${ }^{140}$

Keeping the Russian action in Crimea 2014 in mind, the House of Commons states that the Arctic now has: "the renewed presence of a revisionist state in the region". ${ }^{141}$ The British strategic security and defence priorities should therefore follow two lines: (1) to improve national capacities to counter the perceived growing military threats in the Arctic and North Atlantic, given the capability to both control large areas and deny western activity according to the bastion defence concept, and (2) to work to increase NATO's commitment to and training in the North-Atlantic and Arctic region. ${ }^{142}$ From this perspective, it points out the importance of improving military cooperation with Norway and the USA. ${ }^{143}$ It also emphasises the need for an increased number of soldiers to be deployed for annual winter training in Northern Norway. ${ }^{144}$

\section{France}

As a leading power in Europe, France's assessment of the security climate in the Arctic is important. At the time of writing, France has two Arctic strategy papers of high relevance. First, the MFA's "National roadmap for the Arctic", labelled "The Great Challenge of the Arctic", ${ }^{145}$ and second, a strategy paper from the MoD called "France and the New Strategic Challenges in the Arctic". ${ }^{146}$ While both papers stem from the post Crimea-crisis period in Europe, they have strikingly different outlooks on the security climate and potential for conflict in the Arctic. While the MFA paper 
rightly recognizes that the Arctic "offers room for manoeuvre [...] and has once again become a theatre for contradictory ambitions, especially as Russia's strategic stance changes", the paper essentially paints a picture of the Arctic as a region of cooperation rather than competing strategic interests. ${ }^{147}$ Stating that "the Arctic has progressively become a region of cooperation between the eight [Arctic] countries directly concerned", the French MFA emphasizes positive trends over negative tendencies. ${ }^{148}$ However, as a state with shipping interests the roadmap also reminds readers that France's "armed forces must remain able to use the Arctic Ocean for transit of its naval and air forces, and potentially, for naval air force operations". ${ }^{149}$ Playing down hard security issues, the MFA paper ultimately states that France's main interest in the region "primarily concerns its economy, security and environment, rather than military and defence issues". 150

Contrary to the MFA's Arctic roadmap, the French MoD strategy paper paints a much more disturbing picture of developments in the High North. By warning that the Arctic one day might "become an area of confrontation", infamously labelling the Arctic "a second Middle East", the paper displays grave concerns about its future. ${ }^{151}$ Characterizing the Arctic as a "region of growing strategic interest" where "the prospect for resource exploitation and the opening of new sea routes give the Arctic a new strategic importance", the essence of the paper does not cohere with the message from the French MFA. ${ }^{152}$ This incoherence is particularly visible with respect to how legal regimes relevant to the Arctic are viewed. The MoD statement "The Arctic belongs to no one", ${ }^{153}$ casts doubts on the role of legal regimes in the region, hence, contradicting the message emphasized by the MFA. ${ }^{154}$ While it is reasonable to assume that the French MFA has the upper hand regarding the official French position with respect to interpretation of international law, it is nevertheless a stunning statement, and could potentially put France at odds with key NATO allies as well as "the Arctic 5" (The Arctic Ocean Coastal states: USA, Canada, Denmark/ Greenland, Norway and Russia).

\section{Germany}

Germany has the most important economy in Europe and is therefore a key political power on the continent. Germany's position on international political issues is on this basis often of interest to international relations. In August 2019, the federal government published "Germany's Arctic Policy Guidelines". ${ }^{155}$ This key document reveals Germany's policy priorities and security assessments concerning the Arctic, as seen from Berlin. The policy guidelines do not put the main emphasis on the hard security challenges of the Arctic, but rather on challenges arising from climate change, the need for sustainable development, environmental protection and scientific research. However, Germany also expresses concern over how states, to an increasing extent, are using military means to safeguard their interests in the Arctic, leading to a type of behavior "which could lead to an arms race". ${ }^{156}$ In addition, the 
policy paper points out that "Arctic dual use capabilities and their continued modernization as well as technological progress and strategies for external interference are blurring the boundaries between offensive and defensive courses of action". ${ }^{157}$

While not specific, Berlin sees "the potential for non-cooperative behavior in the Arctic, which endangers economic, environmental and security policy stability in the region and thus also affects Germany's security interests". ${ }^{158}$ Even though the Arctic Policy guidelines do not mention Russia specifically as a potential challenge to Arctic security, it does reiterate the country's NATO obligations. "The federal Government is clearly committed to its Alliance obligation, which stems from its EU and NATO membership, and advocates more intensive involvement in the security policy implications of the Arctic on the part of the EU and NATO". ${ }^{159}$ On this basis, one can assume the Germany does not see itself playing a major role as an individual security actor in the Arctic, but rather leaving this responsibility to its key political and security alliances.

\section{Arctic Security viewed from the North Atlantic states}

When assessing to what degree and to what extent concerns over military threats in the Arctic are reflected in North Atlantic states' Arctic security strategies, a nuanced picture emerges, though with certain similarities. At first glance, it is striking to see how the various states agree on many assessments. Almost without exception, the Russian revival of Cold War military bases and the strengthening of the bastion defence concept with new, highly advanced and very powerful capabilities, tends to worry the western capitals.

While one could argue that the bastion defence concept is essentially defensive in nature, aimed at protecting Russia's second-strike capabilities - the most important being their strategic SSBN's - several critical components of this modernized defence concept could (not surprisingly) also play, or facilitate, an offensive role. From this perspective the improved locations for fighter jets and bomber planes on Arctic islands, in combination with highly capable air denial missile systems and silent attack and multi-role submarines, have alerted the key maritime powers of the North Atlantic, namely the UK and the USA, more so than for example France or a continental power like Germany.

In addition to the two above-mentioned key maritime powers - the UK and the USA - the Arctic security strategies of states in near proximity to, or even partly behind, the geographic reach of the bastion defence, primarily Greenland/Denmark and Norway, also quite directly point to the complex military threat from Russia as a potential challenge to their security. In a quite similar way, one can also identify how Canada, while not being within or directly next to the perimeter of the bastion defence, expresses concerns over new long-range, and sophisticated missile systems. As the current NWS system appears outdated in the face of new threats to the North American continent, the Russian weapon modernization programs have led to a new 
focus on the need for early warning through NORAD cooperation between Canada and the USA.

Following this, the degree to which the revival and strengthening of the Russian bastion defence concept is perceived as a challenge would seem to depend on the military posture and ambitions of the different states in question, as well as mere proximity and geographic location. Among the North-Atlantic states, the US stands out in the way its strategic security concerns essentially reflect its superpower role and ambitions. In pointing out a threat to strategic mobility in the Arctic, and the fear of losing a competitive edge (that is to have a military and technological upper hand in case of a symmetric conflict) in a situation characterized by great power competition, US security concerns for the High North are in essence global in nature. This is particularly visible in the way freedom of navigation and overflight operations in the Arctic have gained importance in US security and defence planning for the region. From this perspective the new, advanced Russian weapon systems, combined with the Kremlin's more assertive military behavior in Europe, are viewed as evidence of problems of great power competition rather than developments inherent to the Arctic or North Atlantic as such. As Russian capacities evolve, challenge and even rival the American armed forces' capacity to dominate the region, ${ }^{160,161}$ such developments threaten the Arctic and North Atlantic's function as a space, or corridor, for the projection of military power to different parts of the world for the superpower.

Besides the USA, it is particularly views from the UK, Norway, Canada and Denmark that articulate concerns about the negative strategic implications of the Russian military build-up in the Arctic. For the UK, the statement from the Defence Committee in the House of Commons goes furthest noting that "the strategic importance of the High North and the North Atlantic to the security of the UK and Europe cannot be overstated". ${ }^{162}$ As an island state in the North Atlantic, the potential of Russia using the Arctic military theatre to threaten or even block communication lines between the USA and Europe, represents a major strategic security challenge to the United Kingdom. This is a threat that in latter years has changed the UK security strategy towards the Arctic, resulting in a much more engaged and robust approach to the region involving its own armed forces.

The same perspective and approach is in many ways also evident in Norway, where, in the event of a crisis, the Russian bastion defence forces, "would reduce Norway's freedom of action and movement on its own territory and limit Allied access to the North Sea and the North Atlantic". ${ }^{163}$ This is a situation that could make it difficult for NATO, and key allies like the USA and UK, to supply Norway in case of a security crisis or war. ${ }^{164}$ The grim assessment of such a situation has led to a strategy of enhanced military cooperation with NATO as well as Norway's key bilateral partners, the USA and the UK.

For Denmark the new Russian air power capacities under development in Franz Josef's land, which have the potential to reach the northern shores of Greenland in the event of a military conflict, ${ }^{165}$ is the development causing the most 
worries in Copenhagen. ${ }^{166}$ While having a sheltered mainland on continental Europe, Denmark's strategic role as the protector of Greenland makes the country's position somewhat similar to Norway and the UK in the way that it is more directly affected by the new Russian capabilities as open lines of communication between Denmark and Greenland can be threatened.

While the two French strategy papers for the Arctic send a mixed message, a crucial aspect of its approach to the High North is that of ensuring access to the region, including the potential utilisation of the Arctic sea routes. In this respect, the French strategies share crucial features with the American ones, emphasizing strategic mobility and freedom of navigation in the Arctic. Germany and to a certain extent Canada stand out as the two most "reserved" states with respect to levering national security ambitions in the Arctic region. This comes with an exception though, with Canada putting domestic security and homeland defence, not least through its NORAD early warning system, at center stage, focusing both on its Arctic residents being secure and well defended, along with the security of the entire North American continent. Germany's role is one of caution when it comes to strategic ambitions towards the Arctic. Despite being a key European power, Germany does not stand out as a leading nation with respect to strategic or military leadership in the High North. Instead, this key role is adopted by the US, acting as the strategic leader among the North Atlantic states in their endeavour to make the Arctic stable, secure, and open to navigation and overflight. However, it is essential to re-emphasize the crucial role that US allies and partners play in keeping American leadership strong and dominant. As stated in the DoD strategy: "The network of U.S. allies and partners with shared national interests in this rules-based order is the United States' greatest strategic advantage in the Arctic region, and thus the cornerstone of DoD's Arctic strategy". ${ }^{167}$

\section{Conclusion}

The colder security climate, following Russia's annexation of Crimea, is reflected in the Arctic today. This tenser situation can be observed in most of the North Atlantic states' security thinking on the Arctic, as well as in changed patterns of military training and operations. However, while at first glance the changes might lead observers to assume that the North West Atlantic states have taken a rather similar approach to the strategic challenges of the High North, the specific Arctic strategies reveal a somewhat different picture.

Most notable when comparing the strategies is the rather unique global perspective laid out in the US strategy for the region. The British, Norwegian, Danish and Canadian perspectives, on the other hand, stand out as much more regional in nature. For the UK, Norway and Denmark the focus is primarily on the threat to the control of communication lines, sea and land territories as well as of their nearby strategic waters. For the UK and Norway, the importance of securing allied presence 
and access to NATO's northern flank in case of crisis is of key importance. Canada, on the other hand, maintains its focus on defending its Arctic homeland, not engaging in the quest for dominance and control in the North Atlantic or Arctic Ocean.

For the US, the question of having a competitive military edge in the Arctic and North Atlantic is crucial, however, its broader focus is not limited to the securitycalculations of this region. Instead, the Arctic plays an interconnected role in American strategic mobility across the globe, in a context of multipolar strategic competition where the US is the world's only military superpower. Hence, the Arctic plays a key role regarding US global leadership in a pressured situation characterized by great power rivalry. Freedom of navigation and overflight, exemplified by the need to have access to the Northern Sea Route, or mobility across the Arctic Ocean, takes center stage in the strategic development of the Arctic, seen from Washington DC. While Germany displays a rather low profile in its approach to the international security in the Arctic, compared to its economic status in Europe, France represents an alternative approach. Filling the role of a major power, Paris reveals a strong concern for Arctic shipping and freedom of navigation, a perspective not substantially different from that of the USA, but with lower global ambitions.

\section{NOTES}

1. Svein Efjestad and Rolf Tamnes: "NATO's Enduring Relevance," Whitehall Papers, 95 (2019): 8, 22 .

2. New York Times: "Allies and Former U.S. Officials Fear Trump Could Seek NATO Exit in a Second Term" Sept. 3 2020, Available at: https://www.nytimes.com/2020/09/03/us/politics/ trump-nato-withdraw.html

3. Barry Buzan, Ole Wæver and Jaap de Wilde. Security a New Framework for Analysis, (Boulder: Lynne Rienner Publishers, 1998), 2-5.

4. Keith Krause and Michael Williams. "Security and Security Studies," in The Oxford Handbook of International Security, eds. Alexandra Gheciu and William Wohlforth, (Oxford: Oxford University Press, 2018), 20-21.

5. Barry Buzan. People States and Fear, (Brighton: Wheatsheaf Books, 1983).

6. Paul Williams. "Security Studies," in Security Studies an introduction, ed. Paul Williams (New York: Routledge, 2013), 3-4.

7. Ibid., 3-4.

8. European Council. EU restrictive measures in response to the crisis in Ukraine. 2020, Available at: https:/www.consilium.europa.eu/en/policies/sanctions/ukraine-crisis/

9. NATO, Wales Summit Declaration Issued by the Heads of State and Government participating in the meeting of the North Atlantic Council in Wales. 5 Sept. 2014. Available at: https://www.nato.int/cps/en/natohq/official_texts_112964.htm

10. Government of Canada. Canadian Sanctions Related to Russia Available at: https://www. international.gc.ca/world-monde/international_relations-relations_internationales/sanctions/russia-russie.aspx?lang=eng

11. US Department of Defence. "European Reassurance Initiative Shifts to Deterrence" 2016. Available at: https:/www.defense.gov/Explore/News/Article/Article/839028/europeanreassurance-initiative-shifts-to-deterrence/ 
Njord Wegge

12. NATO. "NATO takes measures to reinforce collective defence, agrees on support for Ukraine”. 1 April 2014. Available at: https://www.nato.int/cps/en/natohq/news_108508. htm?selectedLocale $=$ en

13. P. Whitney Lackenbauer. "Introduction. Russia Canada and the Ice curtain", in: Breaking the Ice Curtain Russia, Canada, and Arctic Security in a Changing Circumpolar World. Eds: P. Whitney Lackenbauer and Suzanne Lalonde. (Calgary: Canadian Global Affairs Institute 2019).

14. Jakub Godzimirski and Alexander Sergunin. "Russian Expert and Official Geopolitical Narratives on the Arctic: Decoding Topical and Paradigmatic DNA." Arctic Review on Law and Politics. 11 (2020).

15. Lawrence Freedman. "Strategy" (Oxford: Oxford University Press, 2013): X- XII, 88.

16. NATO Term. The official NATO terminology database. Available at: https://nso.nato.int/ natoterm/content/nato/pages/ntp.html?lg=en

17. Juha Käpylä and Harri Mikkola, Harri. "Contemporary Arctic Meets World Politics: Rethinking Arctic Exceptionalism in the Age of Uncertainty," in The Global Arctic Handbook, eds. Matthias Finger and Lassi Heininen (Cham: Springer, 2019), 153-170.

18. See for example Leif Christian Jensen and Geir Hønneland, Handbook on the Politics of the Arctic, (Cheltenham \& Northampton, MA: Edward Elgar, 2015).

19. Barry Buzan, Ole Wæver and Jaap de Wilde. Security A New Framework for Analysis.

20. Mark Nuttall, "Climate change and human security in the Arctic". In Handbook on Climate Change and Human Security, eds. Michael R Redclift and Marco Grasso (Cheltenham: Edward Elgar, 2013).

21. Kamrul Hossain, Gerald Zojer, Wilfrid Greaves, J. Miguel Roncero and Michael Sheehan, "Constructing Arctic security: an unter-disciplinary approach to understanding security in the Barents region", Polar Record, 53 (2017).

22. Njord Wegge, "The political order in the Arctic: power structures, regimes influence," Polar Record, 47 (2011): 166-167.

23. Njord Wegge and Kathrin Keil, "Between Classical and Critical Geopolitics in a Changing Arctic," Polar Geography. 41 (2018).

24. Ibid., 87-91.

25. Klaus Dodds, Merje Kuus and Johanne Sharp. "The Ashgate Research Companion to Critical Geopolitics (Farnham Ashgate Publishing Company, 2013).

26. P. Whitney Lackenbauer and Adam Lajeunesse. "The Canadian Armed Forces in the Arctic: Building Appropriate Capabilities". Fournal of Military and Strategic Studies. 16 (2016)

27. Kristian Åtland, "North European security after the Ukraine conflict", Defense E Security Analysis, 32 (2016): 163-176.

28. Ethan Corbin. "Security Competition Rising: Renewed Militarization of the High North". In, ed. Geoffrey Gresh Eurasia's Maritime Rise and Global Security, (Palgrave Macmillan 2018).

29. John J Hamre and Heather A Conley. "The Centrality of the North Atlantic to NATO and US Strategic Interests”, Whitehall Papers, (2016) 87.

30. Bradford Dismukes, "The Return of Great-Power Competition. Cold War Lessons about Strategic Antisubmarine Warfare and Defense of Sea Lines of Communication”, Naval War College Digital Commons, Summer 2020.

31. Expert Commission, Norwegian Ministry of Defence, (2015): 5-6.

32. Renz, Bettina, Russia's Military Revival. (Cambridge: polity, 2018): 61-120.

33. James Foggo and Alarik Fritz (2018): NATO and the Challenge in the North Atlantic and the Arctic, Whitehall Papers, 95 (2018): 122-125.

34. James Lacey, "Battle of the Bastions", War on the Rocks, January 9, 2020. Available at: https:// warontherocks.com/2020/01/battle-of-the-bastions/ 
35. David W. Orr. "Sea Control in the Arctic: A Soviet Perspective". Naval War College Review. 41 (1988).

36. Expert Commission 2015: 21 .

37. Ibid., 21.

38. Expert Commission 2015: 21

39. Rolf Tamnes, "The High North: A Call for a Competitive Strategy". Whitehall Paper 93 (2018): 11-14.

40. Expert Commission (2015): 20-22.

41. Mathieu Boulègue, "Russia's Military Posture in the Arctic". Research Paper, Chatham House. June (2019): 6-8, 19-20.

42. Ibid., 6-8.

43. Torbjørn Pedersen, "Polar Research and the Secrets of the Arctic" Arctic Review on Law and Politics 10 (2019): 106-107.

44. Mathieu Boulègue, "Russia's Military Posture in the Arctic": 6-7.

45. Jakub Godzimirski and Alexander Sergunin, "Russian Expert and Official Geopolitical Narratives on the Arctic: Decoding Topical and Paradigmatic DNA".

46. President of Russia. "Vladimir Putin approved basic principles of state policy in the Arctic" 5 March 2020. Available at: http://en.kremlin.ru/acts/news/62947

47. Ekaterina Klimenko. "Russia's new Arctic policy document signals continuity rather than change" SIPRI report (6 April 2020).

48. Arms Control Today, «Russia Release Nuclear Deterrence Policy. July/August 2020. Available at: https://www.armscontrol.org/act/2020-07/news/russia-releases-nuclear-deterrence-policy

49. Danish Defence Intelligence Service. Intelligence Risk Assessment 2019: 13.

50. Ibid., 13-14.

51. Ibid., 14 .

52. Ibid., 14 .

53. Ibid., 14 .

54. High North News (2019): "New Satellite Images Reveal Extent of Russia's Military and Economic Build-Up in the Arctic" avaiable at: https://www.highnorthnews.com/en/ new-satellite-images-reveal-extent-russias-military-and-economic-build-arctic

55. Matthew Melino and Heather A. Conley, "The Ice Curtain: Russia's Arctic Military Presence" 2020, Available at: https://www.csis.org/features/ice-curtain-russias-arctic-military-presence.

56. Janes Intelligence Review, "Russia upgrades Northern Fleet HQ". 8 August, 32 (2020), 24.

57. Ibid., 24.

58. Norwegian Intelligence Service. Focus 2020: The Norwegian Intelligence Service's assessment of current security challenges 2020: 10 .

59. Ibid., 10 .

60. The Barents Observer. 30 Russian naval vessels stage show of force near coast of Norway. 15 August 2019. Available at: https://thebarentsobserver.com/en/ security/2019/08/30-russian-naval-vessels-stage-show-force-coast-norway

61. Foggo and Fritz, NATO and the Challenge in the North Atlantic and the Arctic, 122-125.

62. Anne-Marie Brady. CSIS, ChinaPower Podcast. Available at: https://chinapower.csis.org/ podcasts $/$ chinas-arctic-ambitions/?utm_source $=$ CSIS + All\&utm_campaign $=843 \mathrm{de} 9 \mathrm{~d} 64 \mathrm{~b}-$ EMAIL_CAMPAIGN_2018_09_04_03_13_COPY_01\&utm_medium=email\&utm_term= 0_f326fc46b6-843de9d64b-222151521

63. Barents Observer (2018): "Chinese navy commander talks cooperation in Severomorsk" 30 July. Available at: https://thebarentsobserver.com/en/security/2018/07/chinesenavy-commander-talks-cooperation-severomorsk

64. Tormod Heier, "Avoiding War: How Should Northern Europe Respond to the US-Russian Rivalry?”, Arctic Review on Law and Politics (9) 2018. 


\section{Njord Wegge}

65. NATO (2018):Trident Juncture 18, NATO Media resources. Available at: https://www.nato. int/cps/en/natohq/news_158620.htm

66. NATO (2018) STRIKFORNATO exercises integration of Carrier Strike Group Eight. Available at: https://sfn.nato.int/trje 18-8\#: :text=Participation $\% 20$ in $\% 20$ NATO $\% 20$ exercise $\% 20$ Trident, of $\% 20$ Operations $\% 2 \mathrm{C} \% 20$ the $\% 20$ Harry $\% 20$ S.

67. Marine Times (2019): "New Marine rotation arrives in Norway as Corps preps for a coldweather fight". Available at: https://www.marinecorpstimes.com/news/your-military/2019/ 03/29/new-marine-rotation-arrives-in-norway-as-corps-preps-for-a-cold-weather-fight/

68. The Maritime Executive (2018): "U.S. 2nd Fleet Re-established to Counter Russian Navy", available at: https://www.maritime-executive.com/article/u-s-navy-re-establishes-2nd-fleetto-counter-russia.

69. NATO (2019): “JFC Norfolk formally activated by NAC", available at: https://shape.nato. int/news-archive/2019/jfc-norfolk-formally-activated-by-nac.

70. NATO (2019): SNMG 1 Steams into Dynamic Mongoose 2019, NATO Media center. Available at: https://mc.nato.int/media-centre/news/2019/snmg-1-steams-into-dynamic-mongoose2019

71. US Embaqssy to Norway (2020): "U.S., U.K. Ships Operate in the Barents Sea", Available at: https://no.usembassy.gov/u-s-u-k-ships-operate-in-the-barents-sea/

72. Barents Observer (2020): "In a controversial move, Norway sails frigate into Russian economic zone together with U.K. and U.S. navy ships", Available at: https://thebarentsobserver. $\mathrm{com} / \mathrm{en} / \mathrm{security} / 2020 / 09 /$ norwegian-frigate-sails-near-russias-fishermen-peninsula-togetheruk-and-us-ships

73. Barents Observer (2020): "London calling to the faraway north, leads largest NATO task force into the Barents Sea since last Cold War", Available at: https://thebarentsobserver. $\mathrm{com} / \mathrm{en} /$ security/2020/09/london-calling-faraway-north-leads-largest-nato-task-forcebarents-sea-last-cold

74. Ibid.

75. Barents Observer (2020): "U.S. Sixth Fleet enters the Barents Sea with missile defense destroyer", Available at: https:/thebarentsobserver.com/en/security/2020/05/ us-sixth-fleet-enters-barents-sea

76. US Air Force (2019): US Air Force B-2 bomber lands in Iceland, Press Release Number: 070819. Available at: https://www.usafe.af.mil/News/Press-Releases/Article/1945664/ us-air-force-b-2-bombers-land-in-iceland/

77. US Air Force (2019b): "Bomber Task Force returns from flights in the Barents Sea Region, Press Release Number: 011119 Available at: https://www.usafe.af.mil/News/Press-Releases/ Article/2009924/bomber-task-force-returns-from-flights-in-the-barents-sea-region/

78. Barents Observer (2019): "B-2 stealth bomber on mission above Arctic Circle outside Norway”. Available at: https://thebarentsobserver.com/en/security/2019/09/b-2-stealthbomber-first-mission-above-arctic-circle-outside-norway

79. The Barents Observer (2020): "Norwegian fighters fly alongside six B-52 bombers. Available at: https://thebarentsobserver.com/en/security/2020/08/norwegian-fighters-flyalongside-six-b-52-bombers

80. High North News (2019).

81. Tamnes, "The High North: A Call for a Competitive Strategy", 9.

82. Heather A. Conley. "The Arctic Spring. Washington Is Sleeping Through Changes at the Top of the World" Foreign Affairs (September 2019).

83. Heier, "Avoiding War: How Should Northern Europe Respond to the US-Russian Rivalry?", 278. 
84. Jeremy M McKenzie (2019): A Case for a Stronger Partnership with Russia in the Arctic. The Pacific Council on International Policy. Available at: https://www.pacificcouncil.org/ newsroom/case-stronger-partnership-russia-arctic

85. Lassi Heininen, "Special Features of Arctic Geopolitics - A Potential Asset for World Politics". In The Global Arctic Handbook, ed Lassi Heininen, (Cham: Springer, 2018).

86. Congressional Research Service (2020): Changes in the Arctic: Background and Issues for Congress. Updated April 28, R41153, 30-31.

87 US Department of Defence (DoD) Arctic Strategy, (2019).

88. US Coast Guard, Arctic Strategic Outlook, (2019).

89. US Department of the Air Force. Arctic Strategy (2020).

90. US Department of Defence (DoD) National Defence Strategy (2018).

91. General Charles Brown, Air Force Chief of Staff, Accelerate Change or Lose. Strategy paper, August 2020.

92. DoD Arctic Strategy 2019, 2.

93. US Coast Guard, Arctic Strategic Outlook, 4.

94. US Department of the Air Force. Arctic Strategy, 2.

95. DoD Arctic Strategy 2019., 3.

96. Ibid., 4.

97. Ibid., 4 .

98. Ibid., 4 .

99. Ibid., 5-6.

100. Ibid., 7-8.

101. Ibid., 8 .

102. US Department of the Air Force. Arctic Strategy, 9.

103. Ibid., $2,9$.

104. DoD Arctic Strategy 2019,13.

105. Ibid., 2.

106. Ibid., 13.

107. Government of Canada, Arctic and Northern Policy Framework (2019).

108. Canadian Armed Forces, Strong, Secure, Engaged (2017).

109. Arctic and Northern Policy Framework.

110. Ibid.

111. Canadian Armed Forces, Strong, Secure, Engaged, 14, 79.

112. Canadian Armed Forces, Strong, Secure, Engaged, 79.

113. Strong, Secure, Engaged, 14.

114. Strong, Secure, Engaged, 50.

115. Ibid., 50 .

116. Danish Ministry of Foreign Affairs, Foreign and Security Policy Strategy 2019-2020.

117. Kingdom of Denmark, Strategy for the Arctic 2011-2020.

118. Danish Parliament, Defence agreement 2018-2023.

119. Foreign and Security Policy Strategy 2019-2020, 7.

120. Ibid., 26.

121. Ibid., 26.

122. Defence agreement 2018-2023, 1.

123. Government of Norway, Norway's Arctic Strategy - between geopolitics and social development, (2017).

124. Norwegian MFA, Setting the course for Norwegian foreign and security policy, (2016-2017).

125. Norway's Arctic Strategy - between geopolitics and social development, 18.

126. Norwegian MFA, 11. 
127. Norway's Arctic Strategy - between geopolitics and social development, 18.

128. Norwegian MFA, 14.

129. Ibid., 15).

130. Frank Bakke Jensen, Minister of Defence, "Change and stability in the High North", Op Ed published in Defense Nerws, 2 Dec. 2019. Available at: https://www.regjeringen.no/en/aktuelt/ defence-news-2019/id2681026/

131. HM Government, Beyond the Ice, UK policy towards the Arctic, 2018.

132. Ibid., 21.

133. House of Commons, Defence Committee's report: "On Thin Ice: UK Defence in the Arctic" (2018).

134. Ibid., 3,5 .

135. Ibid., 10-11.

136. Ibid., 11.

137. Ibid., 16.

138. Ibid., 20.

139. Ibid., 20.

140. Ibid., 16 .

141. Ibid., 51 .

142. Ibid., 3, 51 .

143. Ibid., 43-50.

144. Ibid., 47.

145. French MFA, National roadmap for the Arctic. The Great Challenge of the Arctic, (2016).

146. French Ministry of Defense, "France and the New Strategic Challenges in the Arctic, (2019).

147. French MFA, National roadmap for the Arctic, 32-33.

148. Ibid., 33.

149. Ibid., 34 .

150. Ibid., 34 .

151. French MoD, France and the New Strategic Challenges in the Arctic, 1.

152. Ibid., 2.

153. Ibid., 1.

154. French MFA National roadmap for the Arctic, 10.

155. Germany's federal government. "Germany's Arctic Policy Guidelines” (2019).

156. Ibid., 23.

157. Ibid., 23.

158. Ibid., 23.

159. Ibid., 25.

160. DoD Arctic Strategy 2019, 2, 6.

161. US Department of the Air Force. Arctic Strategy.

162. House of Commons, 16.

163. Norwegian MFA, 14.

164. Norwegian MFA, 14.

165. Danish Defence Intelligence Service, 13-14.

166. Danish MFA, 26.

167. US DoD Arctic Strategy, 2. 